\title{
Walkability Pada Jalur Pergantian Antarmoda Pada Kawasan Dermaga Kota Palembang
}

\author{
An Nurrakis ${ }^{1)}$, Dyah Titisari Widyastuti ${ }^{2}$ \\ ${ }^{1) 2)}$ Program Studi Magister Arsitektur, Departemen Teknik Arsitektur dan Perancanaan \\ Universitas Gadjah Mada, Yogyakarta \\ Bulaksumur, Caturtunggal, Kec. Depok, Kabupaten Sleman, Daerah Istimewa Yogyakarta 55281 \\ Email: $\underline{\text { an.nurrakis@mail.ugm.ac.id }}{ }^{1)}, \underline{\text { dyahtitisariw@gmail.com }}^{2)}$
}

\begin{abstract}
Musi river which divides the city of Palembang becomes a potential for water moda tranportation. there are four piers in the pier of city palembang. Bekang pier, Point pier, Ampera pier, Pasar 16 pier. The existence of the four piers is a generator for land transportation moda that move around the pier. For people who use land and water transportation, they move on foot, giving rise to pedestrian paths that connect land and water transit points. However, this area is not supported by good pedestrian paths and encourages intermodal users to prefer using motorized vehicles rather than walking in daily activities. To increase walking activities, it needs to be supported by a pleasant, comfortable track and a good pedestrian path. The purpose of this study is to find the level of walkability, and develop strategies to increase the level of walkability that is appropriate in the dock area of Palembang. Walkability level assessment consists of 7 (seven) variables, Accessible variables, Connected variables, Legible variables, Comfortable variables, Safe variables, Secure variables and Pleasant variables. The results show that the level of walkability in the Palembang City pier area is at a very bad level (1.4 on a scale of 5), with safety from pedestrian crime as the most influential component of walkability.
\end{abstract}

Keywords : walkability, intermodal change point, city transportation

\begin{abstract}
ABSTRAK
Sungai musi yang membelah Kota Palembang menjadi potensi bagi moda transportasi air. Terdapat empat titik dermaga pada kawasan Dermaga Kota Palembang, Dermaga Bekang, Dermaga Point, Dermaga Ampera, Dermaga Pasar 16. Keberadaan empat dermaga tersebut menjadi generator bagi moda transportasi darat yang bergerak di sekitar dermaga. Bagi masyarakat pengguna trnasportasi antarmoda darat dan air melakukan perpindahan dengan berjalan kaki sehingga menimbulkan jalur-jalur pejalan kaki yang menghubungkan titik transit antarmoda darat dan air. Namun, kawasan ini tidak didukung oleh jalur pejalan kaki yang baik dan mendorong pengguna antarmoda lebih memilih menggunakan kendaraan bermotor daripada berjalan kaki dalam aktivitas sehari-hari. Untuk meningkatkan aktivitas berjalan, perlu ditunjang dengan suasana jalur yang menyenangkan, nyaman serta jalur pejalan kaki yang baik. Tujuan dari penelitian ini adalah menemukan tingkat walkability, dan menyusun strategi untuk meningkatkan level walkability yang sesuai pada kawasan dermaga kota palembang. Penilaian tingkat walkability terdiri dari 7 (tujuh) variable yaitu, kemudahan akses, keterhubungan, keterbacaan, kenyamanan, keamanan dari lalulintas, keamanan dari kriminal, dan menyenangkan. Hasil menunjukkan bahwa tingkat walkability di kawasan dermaga Kota Palembang berada pada level sangat buruk (1,4 pada skala 5), dengan keamanan dari tindakan kriminal jalur pejalan kaki sebagai komponen walkability yang paling berpengaruh.
\end{abstract}

Kata kunci : walkability, titik-titik pergantian moda, transportasi kota 


\section{Pendahuluan}

Besarnya wilayah kota Palembang memberikan tantangan tersendiri bagi pemerintah untuk menyediakan transportasi antar wilayah yang mampu di akses dengan mudah, cepat, aman dan nyaman untuk memenuhi kebutuhan akan bermobilisasi dari satu tempat ke tempat lain di kota palembang. Pada saat sekarang penggunaan transportasi massal belum banyak dimanfaatkan oleh masyarakat secara optimal dikarenakan masyarakat masih banyak menggunakan kendaraan pribadi.

Pusat dari perpindahan antar moda transportasi yang dijelaskan diatas berada di kawasan Dermaga Point Kota Palembang. Kawasan Dermaga Point Kota Palembang menjadi pusat perpindahan antar moda karena keberadaannya yang tidak jauh dari pusat kota itu sendiri, dimana perpindahan moda transportasi dari tranportasi air dan darat terjadi disana. Perpindahan antar moda tranportasi bagi pengguna masih sangat rendah dilakukan dengan cara berjalan kaki. Pengguna masih banyak menggunakan transportasi seperti (gojek online, becak dll). Misalnya, pengguna transportasi dari titik transit LRT (stasiun) menuju titik transit moda transportasi air (dermaga). Jarak antara stasiun LRT menuju dermaga masih dalam radius 400 meter, tetapi pengguna menuju ke dermaga tidak memilih untuk berjalan kaki. Hal ini dikarenakan kualitas jalur pejalan kaki dari sisi keamanan dan kenyamanan masih sangat rendah/tidak baik. kurangnya penerangan di malam hari. Dampak dari kualitas jalur pejalan kaki yang tidak baik dalam menghubungkan titik-titik transit antar moda transportasi, membuat rendahnya minat masayarakat dalam menggunakan transportasi umum sehingga masih banyak yang menggunakan kendaraan pribadi, padahal transportasi umum di palembang sudah sangat banyak. Oleh sebab itu penerapan konsep walkability pada kawasan Dermaga kota Palembang di butuhkan, sebagai upaya untuk menarik minat masyarakat pengguna jasa moda transportasi darat dan air lebih memilih berjalan kaki dalam berpindah moda transportasi.

Menurut Department of Sport and Recreation (2007), Park S (2008) dan Southworth M (2005) Walkability adalah suatu kondisi yang menggambarkan lingkungan yang mendukung dan mendorong aktivitas berjalan, menghubungkan orang-orang dengan berbagai kegiatan dan tujuan dalam jarak berjalan kaki, dan didukung oleh berbagai fasilitas dan diukur dengan atribut desain perkotaan di tingkat mikro.

Pedestrian Planning and Design Guide yang dikeluarkan New Zealand Tansport Agency (2009), ada 9 karakteristik utama dalam menciptakan lingkungan walkable yaitu Connected, Legible, Comfortable, Convenient, Pleasant, Safe, Secure, Universal, Accessible.

Portland Pedestrian Design Guide (1998) menyebutkan 7 kriteria jalur pejalan kaki yang baik, adalah: Accessibility, Adequate Travel Width, Safety, Continuity, Landscaping, Social Space, Quality of Place. Walk WA: A Walking Strategy for Western Australia (2007-2020) menyebutkan bahwa agar dapat mendukung terciptanya suatu lingkungan yang walkable, ada 4 hal yang harus diperhatikan adalah: Access, Aesthetics, Safety and security, Comfort.

Transport for London (2005), walkability dari suatu tempat dapat dikarakteristikkan dengan singkatan ' $5 \mathrm{C}$ ', adalah: Connectted, Convivial, Conspicuous, Comfortable, Convenient.

Southworth (2005), menyampaikan bahwasanya jaringan yang walkable/ mendorong ornag untuk berjalan kaki, harus memiliki kelengkapan sebagai berikut: Connectivity, Linkage with other motes, Fine grained and varied land use patterns, Safety, Path quality, Path context.

Berdasarkan tinjauan pustaka yang telah dilakukan, ada 7 komponen walkability yaitu Accessible; Connected; Legible; Comfortable; Safe; Secure; dan Pleasant.

Dari 7 komponen jalur pejalan kaki di atas, jika dikaitkan dengan karakteristik jalur pejalan kaki berdasarkan teori yang telah disampaikan sebelumnya, maka dapat dijabarkan sebagai berikut:

Tabel 1. Komponen, Defenisi, dan Parameter Walkability

\begin{tabular}{|c|c|c|}
\hline \multicolumn{3}{|c|}{ Walkability } \\
\hline Komponen & Defenisi & Parameter \\
\hline Accessible & $\begin{array}{lr}\text { Jalur pejalan kaki } \\
\text { yang mudah diakses } \\
\text { oleh semua kalangan } \\
\text { dalam menjalankan } \\
\text { aktivitas r dan } \\
\text { memenuhi kebutuhan } \\
\text { sehari-hari. }\end{array}$ & $\begin{array}{ll}\text { 1. } & \text { Ketersediaan } \\
\text { jalur } \\
\text { 2. } \\
\text { 2ebar jalur } \\
\text { 3ebas } \\
\text { Hambatan } \\
\text { 4. Fasilitas } \\
\text { disabilitas }\end{array}$ \\
\hline Connected & $\begin{array}{l}\text { Jaringan Jalur pejalan } \\
\text { kaki yang menerus } \\
\text { dan terhubung antara } \\
\text { tempat asal dan tujuan }\end{array}$ & $\begin{array}{l}\text { 1. Kemenerusan } \\
\text { dan } \\
\text { Keterhubun } \\
\text { gan antar } \\
\text { jalur } \\
\text { 2. Terhubung } \\
\text { ke titik-titik } \\
\text { transit } \\
\end{array}$ \\
\hline Legible & $\begin{array}{l}\text { Jaringan jalur pejalan } \\
\text { kaki yang jelas, } \\
\text { akurat, berkualitas, } \\
\text { dan mudah ditemukan. }\end{array}$ & 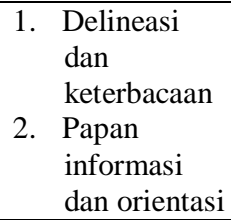 \\
\hline Comfortable & $\begin{array}{l}\text { Jalur pejalan kaki } \\
\text { yang nyaman dengan } \\
\text { permukaan yang tidak } \\
\text { licin, rata dan teduh. }\end{array}$ & 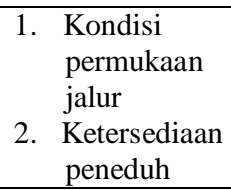 \\
\hline Safe & $\begin{array}{l}\text { Jalur pejalan kaki } \\
\text { yang aman dari } \\
\text { bahaya lalu lintas dan } \\
\text { tempat perlintasan }\end{array}$ & $\begin{array}{ll}\text { 1. } & \text { Aman } \\
\text { terhadap lalu } \\
\text { lintas } \\
\text { 2. } & \text { Konflik } \\
\text { dengan } \\
\text { moda } \\
\text { transportasi } \\
\text { lain }\end{array}$ \\
\hline Secure & $\begin{array}{l}\text { Jalur pejalan kaki } \\
\text { yang aman dari segala } \\
\text { tindakan kriminal. }\end{array}$ & $\begin{array}{ll}\text { 1. } & \text { Keamanan } \\
\text { Lingkungan } \\
\text { Fisik } \\
\text { 2. Keamanan } \\
\end{array}$ \\
\hline
\end{tabular}




\begin{tabular}{llll}
\hline & & & $\begin{array}{l}\text { lingkungan } \\
\text { Sosial }\end{array}$ \\
\hline \multirow{4}{*}{ Pleasant } & Ruang pejalan kaki & 1. & Kualitas \\
& yang menarik, & Pelayanan \\
& menyenangkan, dan \\
mendorong adanya & & \\
interaksi sosial. & \\
\hline
\end{tabular}

Penelitian ini difokuskan pada kondisi jalur pejalan kaki pada kawasan dermaga kota Palembang dalam jarak berjalan kaki yang menghubungkan titik-titik transit moda transportasi. Penelitian ini dapat menjadi salah satu cara untuk mengetahui tingkat keefektifan suatu kawasan dalam mendukung moda trasportasi publik berdasarkan pada parameter-parameter terukur.

Agar penelitian ini tidak meluas, maka perlu membatasi lingkup penelitian. Adapun batasannya adalah sebagai berikut:

1. Identifikasi kondisi jalur pejalan kaki di kawasan Dermaga yang menghubungkan titik-titik transit moda transportasi pada jalur yang sering dilalui oleh masyarakat dan karyawan perusahaan.

2. Pejalan kaki difokuskan pada aktivitas masyarakat dan karyawan dari dan menuju ke tempat bekerja di dalam kawasan dermaga Palembang.

3. Pengumpulan data dan penilaian (scoring) dilakukan oleh peneliti dan berdasarkan persepsi peneliti.

4. Penilaian kondisi jalur pejalan kaki berdasarkan 7 komponen yang menjadi variable penelitian yang telah dirumuskan sebelumnya.

5. Metode yang digunakan adalah deduktif kuantitatif dengan pengumpulan data melalui observasi dan wawancara. Pengambilan sampel menggunakan metode purposive sampling.

6. Observasi dilakukan melalui pengamatan langsung ke lokasi penelitian bertujuan untuk melihat kualitas jalur pejalan kaki. Selain itu dilakukan pengambilan data melalui wawancara pada masyarakat dan karyawan di kawasan Dermaga untuk melihat jalur yang dilalui dan moda transportasi yang digunakan serta alasannya.

7. Purposive sampling merupakan pemilihan anggota sampel yang didasarkan atas tujuan dan pertimbangan tertentu dari peneliti.

Pembagian jalur dilakukan dengan melakukan pengamatan awal pada aktivitas pengguna transportasi antarmoda, rute yang sering digunakan, dan titik-titik transit perpindahan antarmoda di pagi hingga malam hari di area kampus. Penilaian lebih lanjut maka didapatlah pada 10 jalur yang menghubungkan titik-titik transit perpindahan antarmoda, berikut peta jalur-jalur pergantian antarmoda pada kawasan dermaga kota Palembang;

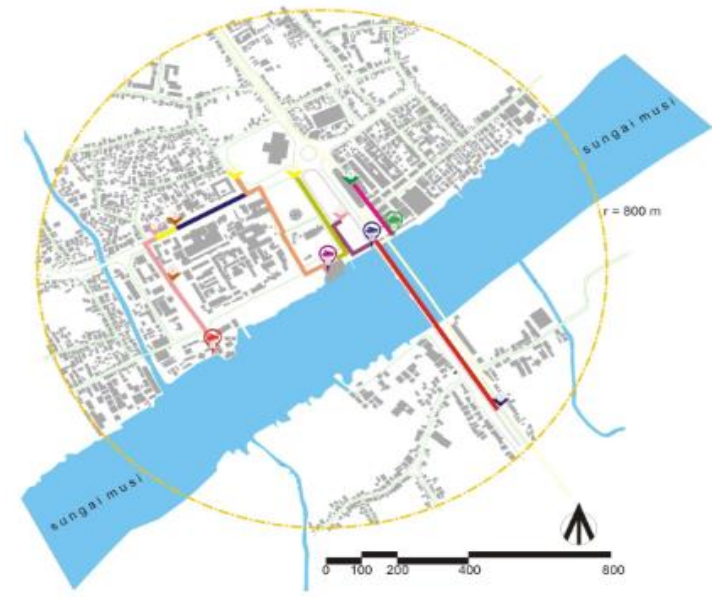

Gambar 1. Pembagian Jalur Pergantian Antarmoda

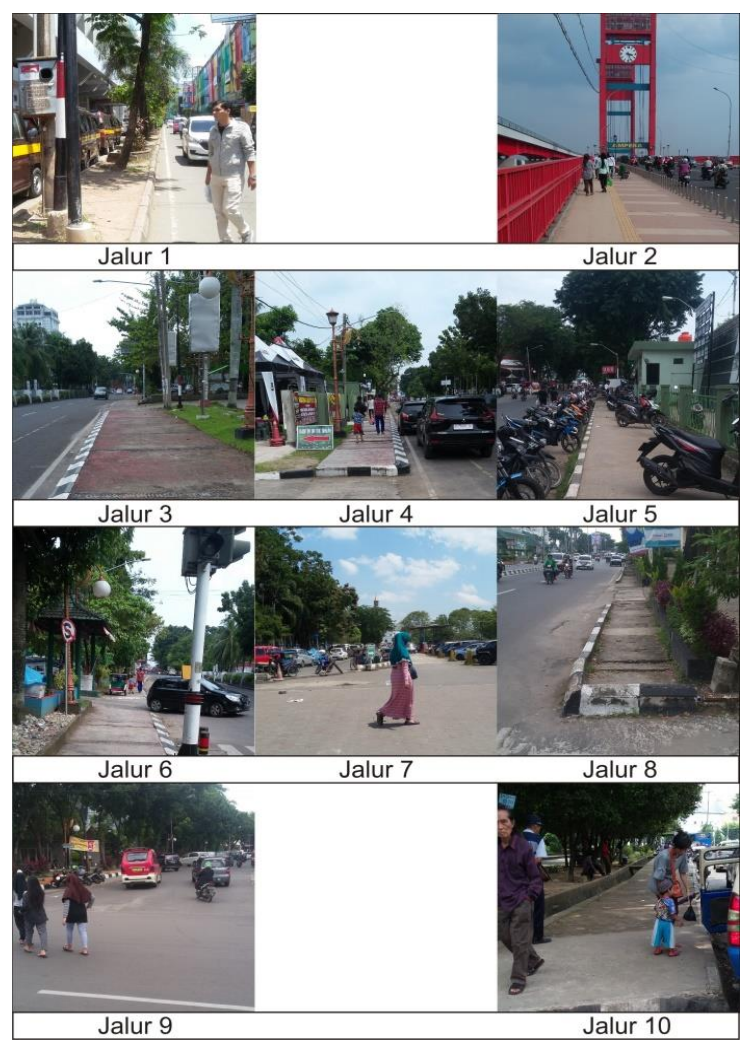

Gambar 2. Foto Jalur Pergantian Antarmoda

Penilaian tingkat walkability di kawasan Dermaga Kota Palembang menggunakan metode penilaian dengan skala 1-5 yaitu 1 (tidak terpenuhi); 2 (sebagian kecil dipenuhi); 3 (sebagian dipenuhi); 4 (sebagian besar dipenuhi); 5 (sepenuhnya terpenuhi). Penilaian walkability panduan tingkat ditentukan sebagai berikut:

Tabel 2. Penilaian Tingkat Walkability pada kawasan Dermaga Kota Palembang

\begin{tabular}{|c|c|}
\hline $\begin{array}{l}\text { Komponen } \\
\text { Walkability }\end{array}$ & Penilaian \\
\hline Accessible & $\begin{array}{l}\text { 1. Ketersediaan jalur; (5) } \geq 90 \% \text {; } \\
\geq 70 \% \text { (4) } \quad(3) \geq 50 \% ; \\
\begin{array}{ll}(1)<25 \% & \text { (2) } \geq 25 \% \text {; }\end{array}\end{array}$ \\
\hline & $\begin{array}{l}\text { 2. Lebar jalur; (5) } \geq 90 \% ; \quad(4) \geq 70 \% \text {; } \\
\text { (3) } \geq 50 \% ;(2) \geq 25 \% ;(1)<25 \%\end{array}$ \\
\hline
\end{tabular}




\begin{tabular}{|c|c|}
\hline & 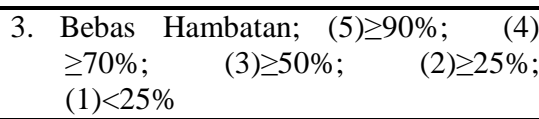 \\
\hline & 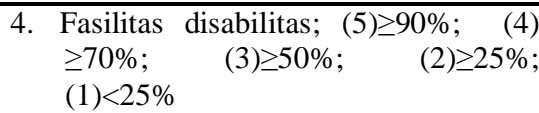 \\
\hline \multirow[b]{2}{*}{ Connected } & $\begin{array}{l}\text { 1. Kemenerusan dan Keterhubungan } \\
\text { antar jalur; }(5) \geq 90 \% ; \quad(4) \geq 70 \% \text {; } \\
\text { (3) } \geq 50 \% ;(2) \geq 25 \% ;(1)<25 \%\end{array}$ \\
\hline & 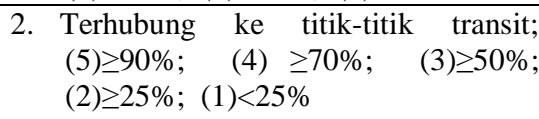 \\
\hline \multirow{2}{*}{ Legible } & $\begin{array}{l}\text { 1. Delineasi dan keterbacaan; }(5) \geq 90 \% \text {; } \\
\begin{array}{ll}\text { (4) } \geq 70 \% ; \quad(3) \geq 50 \% ; & (2) \geq 25 \% \text {; } \\
\text { (1) }<25 \% & \end{array}\end{array}$ \\
\hline & $\begin{array}{lll}\text { 2. Papan informasi dan } & \text { orientasi; } \\
& (5) \geq 90 \% ; \quad(4) \geq 70 \% ; & (3) \geq 50 \% \text {; } \\
& (2) \geq 25 \% ; \quad(1)<25 \% & \end{array}$ \\
\hline \multirow{2}{*}{ Comfortable } & $\begin{array}{l}\text { 1. Kondisi permukaan jalur; }(5) \geq 90 \% \text {; } \\
\begin{array}{ll}\text { (4) } \geq 70 \% ; & (3) \geq 50 \% ; \\
\text { (1) }<25 \%\end{array}\end{array}$ \\
\hline & $\begin{array}{ll}\text { 2. } & \text { Ketersediaan peneduh; }(5) \geq 90 \% ; \quad \text { (4) } \\
\geq 70 \% ; \quad(3) \geq 50 \% ; \quad(2) \geq 25 \% \text {; } & \\
& (1)<25 \%\end{array}$ \\
\hline \multirow{2}{*}{ Safe } & $\begin{array}{l}\text { 1. Aman terhadap lalu lintas; }(5) \geq 90 \% \text {; } \\
\begin{array}{ll}\text { (4) } \geq 70 \% ; \quad(3) \geq 50 \% ; & (2) \geq 25 \% \text {; } \\
\text { (1) }<25 \%\end{array}\end{array}$ \\
\hline & $\begin{array}{l}\text { 2. Konflik dengan moda transportasi } \\
\text { lain; }(5) \geq 90 \% ; \quad(4) \geq 70 \% ; \quad(3) \geq 50 \% \text {; } \\
\text { (2) } \geq 25 \% ;(1)<25 \%\end{array}$ \\
\hline \multirow{2}{*}{ Secure } & 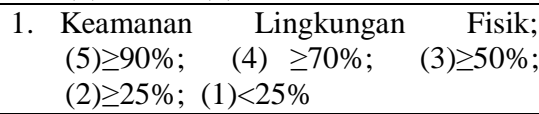 \\
\hline & $\begin{array}{lll}\text { 2. } & \text { Keamanan } \quad \text { lingkungan } & \text { Sosial; } \\
& (5) \geq 90 \% ; \quad(4) \geq 70 \% ; & (3) \geq 50 \% \text {; } \\
& (2) \geq 25 \% ; \quad(1)<25 \% & \\
\end{array}$ \\
\hline Pleasant & $\begin{array}{lll}\text { 1. Kualitas } & \text { Pelayanan; }(5) \geq 90 \% ; \quad(4) \\
\geq 70 \% ; & (3) \geq 50 \% ; \quad(2) \geq 25 \% \text {; } \\
& \end{array}$ \\
\hline
\end{tabular}

\section{Pembahasan}

Dari analisa ke-10 jalur, hasil yang didapatkan sebagai berikut:

1. Accessible (kemudahan akses)

Variabel Kemudahan Akses nilai tertinggi pada Jalur 2. Dengan parameter Ketersediaan Jalur bernilai $80 \%$; parameter Lebar Jalur nilai tertinggi pada jalur 2 bernilai 100\%; parameter Bebas Hambatan tidak tercapai; dan parameter Fasilitas Disabilitas nilai tertinggi pada jalur 2 bernilai $60 \%$.

2. Connected (keterhubungan)

Variabel Keterhubungan dengan parameter Kemenerusan dan Keterhubungan Antar Jalur nilai tertinggi terdapat pada Jalur 2 dengan nilai $60 \%$ dan parameter Terhubung ke Titik-titik Antarmoda nilai tertinggi terdapat pada Jalur 1 dengan nilai $60 \%$.

3. Legible (keterbacaan)

Variabel keterbacaan dengan parameter Delineasi nilai tertinggi pada jalur 9 bernilai $60 \%$ dan Keterbacaan serta Papan Informasi dan Orientasi secara keseluruhan tidak tercapai.

4. Comfortable (kenyamanan)
Variabel Kenyamanan nilai tertinggi pada jalur 1. Dengan parameter Kondisi Permukaan Jalur tidak tercapai dan parameter Ketersediaan Peneduh bernilai $60 \%$.

5. Safe (keamanan dari lalu lintas)

Variabel Keamanan dari Lalu Lintas. Dengan parameter Aman terhadap Lalu Lintas dan parameter Konflik Moda Transportasi Lain secara menyeluruh tidak tercapai.

6. Secure (keamanan dari tindakan kriminal)

Variabel Keamanan dari Tindakan Kriminal dengan parameter Keamanan Lingkungan Fisik nilai tertinggi terdapat pada Jalur 1 dengan nilai 50\% dan parameter Keamanan Lingkungan Sosial nilai tertinggi terdapat pada Jalur 1 dengan nilai $60 \%$.

7. Pleasant (Menyenangkan)

Variabel menyenangkan dengan parameter Kualitas Pelayanan secara keseluruhan tidak tercapai.

Dari penilaian tingkat walkability yang telah dilakukan secara keseluruhan rata-rata dari ke-9 jalur tersebut memiliki nilai 1,7 dan termasuk dalam kategori sangat buruk.

Tabel 3. Tingkat Walkability Kawasan Dermaga Kota Palembang

\begin{tabular}{ccccccccc}
\hline \multirow{2}{*}{ Jalur } & \multicolumn{7}{c}{ Variabel Walkability } & $\begin{array}{c}\text { Tingkat } \\
\text { Walkability }\end{array}$ \\
\cline { 2 - 7 } & $\mathrm{A}$ & $\mathrm{B}$ & $\mathrm{C}$ & $\mathrm{D}$ & $\mathrm{E}$ & $\mathrm{F}$ & $\mathrm{G}$ & Walk,1 \\
\hline 1 & 1,5 & 2,5 & 1,5 & 2,5 & 2 & 2,5 & 2 & $\mathbf{2 , 1}$ \\
\hline 2 & 3,2 & 2,5 & 2 & 1,5 & 2 & 1 & 2 & 2 \\
\hline 3 & 2,2 & 1,5 & 1,5 & 1,5 & 2 & 1 & 1 & 1,5 \\
\hline 4 & 2,2 & 1,5 & 1,5 & 1,5 & 2 & 1 & 2 & 1,7 \\
\hline 5 & 2 & 2 & 1,5 & 2 & 2 & 1,5 & 2 & 1,9 \\
\hline 6 & 2,2 & 1,5 & 1,5 & 1,5 & 2 & 1 & 2 & 1,7 \\
\hline 7 & 1,5 & 1,5 & 1,5 & 1 & 1,5 & 1 & 2 & $\mathbf{1 , 4}$ \\
\hline 8 & 1,7 & 2 & 1,5 & 1 & 2 & 1 & 2 & 1,6 \\
\hline 9 & 2,5 & 2 & 2 & 1,5 & 2 & 1 & 2 & 1,9 \\
\hline 10 & 2,2 & 2 & 1,5 & 1,5 & 2 & 1 & 2 & 1,7 \\
\hline $\begin{array}{c}\text { Rata- } \\
\text { rata }\end{array}$ & $\mathbf{2 , 1}$ & 1,9 & 1,6 & 1,5 & 1,9 & $\mathbf{1 , 2}$ & 1,9 & 1,7 \\
\hline
\end{tabular}

Grafik 1. Tingkat Walkability Kawasan Dermaga Kota Palembang

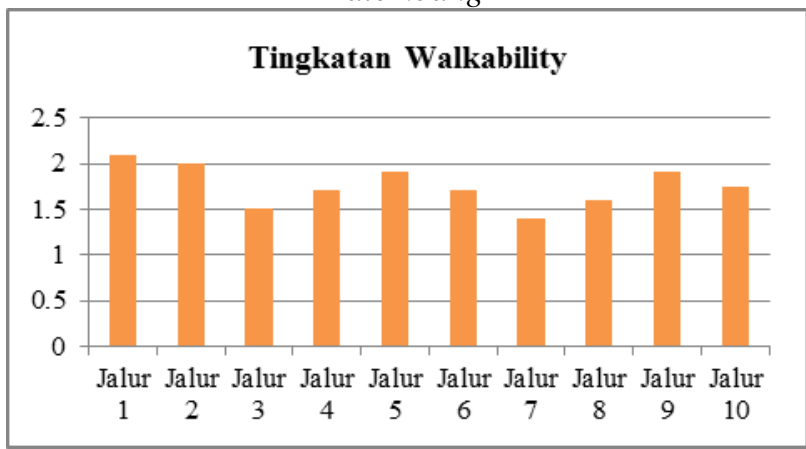

\section{Kesimpulan}

Berdasarkan data dan analisa serta penilaian tingkat walkability yang telah dilakukan, secara umum tingkat walkability pada kawasan Dermaga Kota Palembang bernilai 1,75 (sangat buruk). Berdasarkan hasil analisa tingkat walkability ditemukan beberapa komponen yang 
mempengaruhi tingkat walkability pada jalur pergantian antarmoda pada kawasan Dermaga Kota Palembang yaitu Ketersediaan jalur pejalan kaki, kemenerusan dan keterhubungan antar jalur, ketersediaan peneduh, bebas hambatan, kondisi permukaan jalur, aman terhadap lalu lintas, konflik dengan moda transportasi lain, dan keamanan lingkungan fisik. Agar kawasan dapat menjadi Walkable maka harus memperhatikan elemen yang sudah di sebutkan di atas.

Banyak aspek yang harus di perhatikan dan terpenuhi untuk mewujutkan suatu kawasan yang walkable sehingga melibatkan para pemangku kebijakan, dukungan dan kerjasama dari semua pihak. Berikut elemen-elemen yang berpotensi untuk menjadikan kawasan Dermaga kota Palembang menjadi kawasan yang walkable:

Berdasarkan data dan analisa serta penilaian tingkat walkability yang telah dilakukan, secara umum tingkat walkability pada kawasan Dermaga Kota Palembang bernilai (SANGAT BURUK). Maka perlu adanya saran untuk meningkatkan kualitas jalur agar menjadi kawasan yang walkable:

\section{A. Jalur 1 (Jl. Tengkuruk Permai - Jl. Pasar 16)}

Jalur ini memiliki lebar yang tidak menampung jalur pejalan kaki pada 1 sisi jalan dan diletakkan pada sisi dominan fasilitas pendukung aktivitas. Berikut rinciannya:

1. Untuk meningkatkan kemudahan akses, menyediakan ruang pejalan kaki yang dilengkapi dengan zona perabot, zona pejalan kaki, dan zona depan gedung.

2. Untuk meningkatkan keterhubungan jalur pejalan kaki diletakkan pada sisi yang sama.

3. Untuk meningkatkan keterbacaan, papan informasi dan pengarah jalan (wayfinding) diletakkan pada tiang lampu agar mudah dijangkau secara visual serta di persimpangan jalan.

4. Untuk meningkatkan kenyamanan, pada ketersediaan peneduh sudah cukup baik sehingga yang perlu ditingkatkan yaitu kondisi permukaan jalur yang rata dan tidak licin.

5. Untuk meningkatkan kualitas pelayanan, menyediakan amenitas yang tertata berupa bangku istirahat, tempat interaksi, dan tempat sampah yang ditempatkan di zona perabot.

\section{B. Jalur 2 (Jl. Mayjen H.M Ryacudu)}

Jalur ini memiliki lebar yang cukup menampung jalur pejalan kaki pada 1 sisi jalan dan diletakkan pada sisi dominan fasilitas pendukung aktivitas. Berikut rinciannya:

1. Untuk meningkatkan kemudahan akses, menyediakan ruang pejalan kaki yang dilengkapi dengan zona perabot dan zona perdagangan, ruang pelanggan, serta zona pejalan kaki.

2. Untuk meningkatkan keterhubungan jalur pejalan kaki diletakkan pada sisi yang sama.

3. Untuk meningkatkan keterbacaan, papan informasi dan pengarah jalan (wayfinding) diletakkan pada tiang lampu agar mudah dijangkau secara visual.
4. Untuk meningkatkan kualitas pelayanan, menyediakan amenitas yang tertata berupa bangku istirahat, tempat interaksi, tempat sampah, dan tempat perdagangan yang ditempatkan di zona perabot.

\section{Jalur 3 (Jl. Rumah Bari)}

Jalur ini memiliki lebar yang bervariasi sehingga penempatan jalur pejalan kaki disesuaikan dengan kebutuhan dan diletakkan pada sisi jalan yang memiliki fasilitas pendukung aktivitas. Berikut rinciannya:

1. Untuk meningkatkan kemudahan akses, menyediakan ruang pejalan kaki yang dilengkapi dengan zona perabot dan zona pejalan kaki. Selain itu, menyediakan tempat parkir di tepi jalan agar tidak mengganggu akses pejalan kaki dikarenakan banyak parkir liar.

2. Untuk meningkatkan keterbacaan, papan informasi dan pengarah jalan (wayfinding) diletakkan pada tiang lampu dan kanopi bangunan agar mudah dijangkau secara visual.

3. Untuk meningkatkan kualitas pelayanan, menyediakan amenitas yang tertata berupa bangku istirahat, tempat interaksi, dan tempat sampah yang ditempatkan di zona perabot.

\section{Jalur 4 (Jl. Merdeka-Jl. Rumah Bari)}

Jalur ini memiliki lebar yang bervariasi sehingga penempatan jalur pejalan kaki disesuaikan dengan kebutuhan dan diletakkan pada sisi dominan fasilitas pendukung aktivitas. Berikut rinciannya:

1. Untuk meningkatkan kemudahan akses, menyediakan ruang pejalan kaki yang dilengkapi dengan zona perabot dan zona perdagangan, ruang pelanggan, serta zona pejalan kaki. Selain itu, menyediakan tempat parkir di tepi jalan (pada bagian yang banyak terdapat parkir) agar tidak mengganggu akses pejalan kaki.

2. Untuk meningkatkan keterbacaan, papan informasi dan pengarah jalan (wayfinding) diletakkan pada tiang lampu agar mudah dijangkau secara visual.

3. Untuk meningkatkan kualitas pelayanan, menyediakan amenitas yang tertata berupa bangku istirahat, tempat interaksi, tempat sampah, dan tempat perdagangan yang ditempatkan di zona perabot.

E. Jalur 5 (Jl. Merdeka-Jl. Dr. Ak. Gani-Jl. Sultan Mahmud Badarudin)

Jalur ini memiliki lebar yang cukup untuk menampung jalur pejalan kaki di kedua sisi jalan. Berikut rinciannya:

1. Untuk meningkatkan kemudahan akses, menyediakan ruang pejalan kaki yang dilengkapi dengan zona perabot dan zona pejalan kaki. Selain itu, menyediakan tempat parkir di tepi jalan agar tidak mengganggu akses pejalan kaki.

2. Untuk meningkatkan keterbacaan, papan informasi dan pengarah jalan (wayfinding) diletakkan pada tiang lampu agar mudah dijangkau secara visual. 
3. Untuk meningkatkan kualitas pelayanan, menyediakan amenitas yang tertata berupa bangku istirahat, tempat interaksi, dan tempat sampah yang ditempatkan di zona perabot.

\section{F. Jalur 6 (Jl. Merdeka-Jl. Rumah Bari)}

Jalur ini memiliki lebar yang cukup menampung jalur pejalan kaki pada 1 sisi jalan dan diletakkan pada sisi dominan fasilitas pendukung aktivitas. Berikut rinciannya:

1. Untuk meningkatkan kemudahan akses, menyediakan ruang pejalan kaki yang dilengkapi dengan zona perabot dan zona pejalan kaki.

2. Untuk meningkatkan keterhubungan jalur pejalan kaki diletakkan pada sisi yang sama.

3. Untuk meningkatkan keterbacaan, papan informasi dan pengarah jalan (wayfinding) diletakkan pada tiang lampu agar mudah dijangkau secara visual.

4. Untuk meningkatkan kualitas pelayanan, menyediakan amenitas yang tertata berupa bangku istirahat, tempat interaksi, dan tempat sampah yang ditempatkan di zona perabot.

\section{G. Jalur 7 (Jl. Tengkuruk Permai-Jl. Sultan Mahmud Badarudin)}

Jalur ini memiliki lebar yang cukup menampung jalur pejalan kaki pada 1 sisi jalan dan diletakkan pada sisi dominan fasilitas pendukung aktivitas. Berikut rinciannya:

1. Untuk meningkatkan kemudahan akses, menyediakan ruang pejalan kaki yang dilengkapi dengan zona perabot dan zona pejalan kaki.

2. Untuk meningkatkan keterbacaan, papan informasi dan pengarah jalan (wayfinding) diletakkan pada kanopi bangunan agar mudah dijangkau secara visual.

\section{H. Jalur 8 (Jl. Faqih Jalaludin-Jl. Merdeka-Jl. Rumah Bari)}

Jalur ini memiliki lebar yang bervariasi sehingga penempatan jalur pejalan kaki disesuaikan dengan kebutuhan dan diletakkan pada sisi jalan yang memiliki fasilitas pendukung aktivitas. Berikut rinciannya:

1. Untuk meningkatkan kemudahan akses, menyediakan ruang pejalan kaki yang dilengkapi dengan zona perabot dan zona perdagangan, ruang pelanggan, serta zona pejalan kaki. Selain itu, menyediakan tempat parkir di tepi jalan (pada bagian yang banyak terdapat parkir) agar tidak mengganggu akses pejalan kaki.

2. Untuk meningkatkan keterbacaan, papan informasi dan pengarah jalan (wayfinding) diletakkan pada tiang lampu agar mudah dijangkau secara visual.

3. Untuk meningkatkan kualitas pelayanan, menyediakan amenitas yang tertata berupa bangku istirahat, tempat interaksi, tempat sampah, dan tempat perdagangan yang ditempatkan di zona perabot.
I. Jalur 9 (Jl. Faqih Jalaludin-Jl. Dr. Ak. Gani-Jl. $S M B)$

Jalur ini memiliki lebar yang cukup menampung jalur pejalan kaki pada 1 sisi jalan dan diletakkan pada sisi dominan fasilitas pendukung aktivitas. Berikut rinciannya:

1. Untuk meningkatkan kemudahan akses, menyediakan ruang pejalan kaki yang dilengkapi dengan zona perabot dan zona perdagangan, ruang pelanggan, serta zona pejalan kaki. Selain itu, menyediakan tempat parkir di tepi jalan (pada bagian yang banyak terdapat parkir) agar tidak mengganggu akses pejalan kaki.

2. Untuk meningkatkan keterbacaan, papan informasi dan pengarah jalan (wayfinding) diletakkan pada tiang lampu agar mudah dijangkau secara visual.

3. Untuk meningkatkan kualitas pelayanan, menyediakan amenitas yang tertata berupa bangku istirahat, tempat interaksi, tempat sampah, dan tempat perdagangan yang ditempatkan di zona perabot.

\section{J. Jalur 10 (Jl. Palembang Darussalam)}

Jalur ini memiliki lebar yang cukup menampung jalur pejalan kaki pada 1 sisi jalan dan diletakkan pada sisi dominan fasilitas pendukung aktivitas. Berikut rinciannya:

1. Untuk meningkatkan kemudahan akses, menyediakan ruang pejalan kaki yang dilengkapi dengan zona perabot dan zona perdagangan, ruang pelanggan, serta zona pejalan kaki. Selain itu, menyediakan tempat parkir di tepi jalan (pada bagian yang banyak terdapat parkir) agar tidak mengganggu akses pejalan kaki.

2. Untuk meningkatkan keterbacaan, papan informasi dan pengarah jalan (wayfinding) diletakkan pada tiang lampu agar mudah dijangkau secara visual.

3. Untuk meningkatkan kualitas pelayanan, menyediakan amenitas yang tertata berupa bangku istirahat, tempat interaksi, tempat sampah, dan tempat perdagangan yang ditempatkan di zona perabot.

\section{Daftar Pustaka}

City of Portland 1998 Portland Pedestrian Design Guide.

Department of Sport and Recreation 2007 Walk WA: A Walking Strategy for Western Australia 2007 2020.

New Zeland Transport Agency 2009 Pedestrian Planning and Design Guide.

Park S 2008 Defining, Measuring, and Evaluating Path Walkability, and Testing its Impacts on Transit Users 'Mode Choice and Walking Distance to the Station (University of California).

Southworth M, 2005 Designing The Walkable City Journal of Urban Planning and Development Volume 131 pp 246-257. 
Transport for London 2005 Improving Walkability Good Practice Guidance on Improving Pedestrian Conditions as Part of Development Opportunities. 